\title{
Recruitment of juvenile fishes into a small temperate choked lagoon (Argentina) and the influence of environmental factors during the process
}

\author{
Daniel O. Bruno ${ }^{1}$, María B. Cousseau ${ }^{2,3}$, Juan M. Díaz de Astarloa ${ }^{2,4}$, Eduardo M. Acha ${ }^{4,5}$ \\ ${ }^{1}$ Laboratorio de Ecología, Fisiología y Evolución de Organismos Acuáticos. Centro Austral de Investigaciones Científicas \\ (CADIC-CONICET), Bernardo Houssay 200, 9410 Ushuaia, Argentina. E-mail: dobruno.ush@gmail.com \\ ${ }^{2}$ Laboratorio de Biotaxonomía Morfológica y Molecular de Peces (BIMOPE). Facultad de Ciencias Exactas y Naturales. \\ Universidad Nacional de Mar del Plata, Deán Funes 3350, B7602AYL Mar del Plata, Argentina. \\ ${ }^{3}$ Laboratorio de Ictiología. Facultad de Ciencias Exactas y Naturales. Universidad Nacional de Mar del Plata, \\ Deán Funes 3350, B7602AYL Mar del Plata, Argentina. \\ ${ }^{4}$ Instituto de Investigaciones Marinas y Costeras (IIMyC-CONICET), Deán Funes 3350, \\ B7602AYL Mar del Plata, Argentina. \\ ${ }^{5}$ Instituto Nacional de Investigación y Desarrollo Pesquero (INIDEP), Paseo Victoria Ocampo No 1, CC 175, B7602HSA
} Mar del Plata, Argentina.

\begin{abstract}
Summary: Juvenile fishes were sampled every 15 days from September 2009 to April 2010 along the marine-estuarine gradient (surf zone, estuary and a freshwater stream) of the Mar Chiquita lagoon, Argentina. The temporal variations of juvenile assemblages in spring-summer and the environmental variables related to the spatial and temporal patterns were analysed. Four groups of sampling stations were defined, indicating differences in fish composition among zones during the springearly summer period (Groups I to III), while the composition of juvenile fishes was homogeneous along the marine-estuarine gradient during the late summer-early autumn period (Group IV). Platanichthys platana and Ramnogaster arcuata (Group A) and Odontesthes argentinensis and Brevoortia aurea (Group B) contributed most to the temporal differences observed. The three first species reached this estuarine system in spring, although with lower abundances than in early summer, while B. aurea was dominant in late summer-early autumn, showing different periods of recruitment of these species into the lagoon. After factoring out variation due to shared spatial-temporal-environmental factors (4.43\%), canonical correspondence analysis (CCA) showed that temporal factors had an almost five times greater contribution (15.15\%) than spatial factors $(2.85 \%)$ and almost twice as great as the pure environmental factors $(8.11 \%)$ to explaining the variation in abundance of the juvenile fishes. From the significant environmental variables incorporated in the CCA, wind direction contributed more than water temperature, salinity or transparency in explaining data variability. Indeed, most species were related to "onshore winds" and therefore the importance of wind in the successful recruitment of juveniles into this shallow and micro-tidal estuary is discussed.
\end{abstract}

Keywords: nursery grounds; fish; juvenile; brackish water environment; surf zone; environmental factors; winds; Mar Chiquita coastal lagoon.

Reclutamiento de juveniles de peces a una pequeña laguna semi-obturada de clima templado (Argentina) y la influencia de factores ambientales durante el proceso

Resumen: Los juveniles de peces se recolectaron cada 15 días desde septiembre de 2009 a abril de 2010 a lo largo de un gradiente marino-estuarino (en una zona de rompiente, estuario y un arroyo de agua dulce) de la laguna costera Mar Chiquita (Argentina). Se analizaron las variaciones temporales de las asociaciones de juveniles durante el periodo primavera-verano y las variables ambientales que estuvieron relacionadas con los patrones espaciales y temporales. Fueron definidos cuatro grupos de estaciones de muestreo indicando diferencias en la composición de peces entre zonas durante el período de primaveraverano temprano (grupos I a III), mientras que la composición de peces juveniles fue homogénea a lo largo del gradiente marino-estuarino durante el período de verano tardío-otoño temprano (grupo IV). Platanichthys platana y Ramnogaster arcuata (Grupo A), y Odontesthes argentinensis y Brevoortia aurea (Grupo B) fueron las especies que más contribuyeron a las diferencias temporales observadas. Las tres primeras especies llegaron a este sistema estuarino durante la primavera, aunque con menor abundancia en relación a la registrada en verano temprano, mientras que $B$. aurea fue dominante durante el verano tardío-otoño temprano, mostrando períodos de reclutamiento a la laguna distintos. Después de factorizar la variación compartida entre el factor espacial, el temporal y las variables ambientales (4.43\%), el análisis de correspondencia canónica (CCA) mostró que el componente temporal tuvo una contribución casi 5 veces mayor (15.15\%) a la del componente espacial $(2.85 \%)$, y casi el doble a la de los factores puramente ambientales $(8.11 \%)$ para explicar la variación en la abundancia de los juveniles de peces. De las variables ambientales significativas que fueron incorporadas en el CCA, la dirección del viento contribuyó más que la temperatura, la salinidad o la transparencia del agua en explicar la variabilidad de los datos. De hecho, la mayoría de las especies estuvieron relacionadas con los "vientos marinos" y, por lo tanto, se discute la importancia del viento en el éxito del reclutamiento de juveniles de peces a este estuario poco profundo y de régimen micro-mareal. 
Palabras clave: área de cría; peces; juveniles; ambiente salobre; zona de rompiente; variables ambientales; vientos; laguna costera Mar Chiquita.

Citation/Como citar este artículo: Bruno D.O., Cousseau M.B, Díaz de Astarloa J.M., Acha E.M. 2015. Recruitment of juvenile fishes into a small temperate choked lagoon (Argentina) and the influence of environmental factors during the process. Sci. Mar. 79(1): 43-55. doi: http://dx.doi.org/10.3989/scimar.04085.02A

Editor: A. Sabatés.

Received: April 29, 2014. Accepted: October 15, 2014. Published: January 9, 2015.

Copyright: (C) 2015 CSIC. This is an open-access article distributed under the Creative Commons Attribution-Non Commercial Lisence (by-nc) Spain 3.0.

\section{INTRODUCTION}

The majority of fishes found in estuaries represent those euryhaline marine teleosts that enter these systems in large numbers at particular intervals of their life cycles. Since this immigration typically applies to the young-of-the-year (YOY) class, estuaries are often referred to as fish nursery areas (Potter et al. 1990).

The recruitment process into estuaries is presumably in response to certain environmental cues (odours, turbidity and/or salinity gradients) transported into the marine environment from either estuarine or freshwater sources (Whitfield 1994, Strydom 2003) and/or to tidal currents, particularly in sufficiently deep estuaries where vertical movements of young fishes exploiting flood and/or ebb currents have been proposed (Boehlert and Mundy 1988, Harris et al. 2001). These findings also explain why fish larvae and juveniles congregate in the surf zones adjacent to estuaries before colonizing them (e.g. Harris et al. 2001, Watt-Pringle and Strydom 2003). Once in the estuary, the distribution of juveniles of marine migrant species results from the responses of individuals to multiple environmental variables, which can be either highly dynamic (e.g. salinity, temperature, food availability) or fairly stable (e.g. sediment type, presence of sea grass meadows) (Stoner et al. 2001, Vasconcelos et al. 2010).

Seasonality in estuarine fish assemblages, however, is mainly attributed to the phasing of events that regulate spawning times in marine waters and larval drift to the coast (Potter et al. 2001). In temperate ecosystems, juveniles inhabit estuaries mostly throughout spring and summer, benefiting from suitable conditions for growth, namely high food availability and water temperature (Blaber and Blaber 1980, Potter et al. 1990), though with some associated physiological cost due to natural (e.g. lower salinity) or artificial (e.g. pollution) stressors (Amara et al. 2007).

In temperate Argentine waters, fish reproduction activity of most species spans from late winter to late summer (i.e. September to April, Cousseau and Perrotta 2004). In the northern region of the Argentine continental shelf, two major nursery grounds have been recognized for coastal fishes: the Río de la Plata estuary $\left(35^{\circ} \mathrm{S} 56^{\circ} \mathrm{W}\right)$ and the El Rincón-Bahía Blanca estuary $\left(40^{\circ} \mathrm{S} 62^{\circ} \mathrm{W}\right)$ (Sánchez and Ciechomski 1995). Both are large estuarine systems having in common most of their ichthyofauna. In between, the small (46 $\mathrm{km})$ and very shallow (0.8-3.0 m) "Mar Chiquita" choked lagoon $\left(37^{\circ} 32^{\prime} \mathrm{S} 57^{\circ} 19^{\prime} \mathrm{W}\right)$ is located. Al- though the role of this small lagoon as a nursery ground for fishes has been largely recognized (e.g. Martinetto et al. 2007, González-Castro et al. 2009, Valiñas et al. 2010), neither the temporal pattern of juvenile assemblages occupying the marine and the estuarine environments nor the factors which drive the recruitment process have been documented. Fishes enter the lagoon not only as juveniles but also as larvae; those tiny stages characterized by poor swimming abilities take advantage of wind-driven currents to recruit into the lagoon (Bruno et al. 2014). Though juveniles do not necessarily require assistance of currents to move, they may use them to increase the surplus power (energy per unit time) in order to save energy that could be channeled into growth (Miller et al. 1985).

Therefore, this study aims to assess the recruitment of juvenile fishes into a micro-tidal and shallow temperate choked lagoon. In order to do so, the temporal variation of juvenile assemblages in spring-summer was analysed along three different locations: the surf zone, the estuary and a freshwater stream. The main environmental variables which drive the recruitment process of juveniles were also evaluated. Specifically, we expected that winds and/or tides, which rule Mar Chiquita's water level oscillations (Reta et al. 2001), could be driving the recruitment of juveniles into the lagoon.

\section{MATERIALS AND METHODS}

\section{Study area}

The study area included the surf zone adjacent to Mar Chiquita lagoon's mouth, the lagoon's inlet channel and the Vivoratá stream which discharges into the inlet channel (Fig. 1). A brief description of each type of environment is given below.

Surf zone: the region where the lagoon discharges to the sea is characterized by sandy beaches (Merlotto and Bértola 2009) with surf zones of moderate energy for the most part of the year (Bértola 2006). However, strong southeasterly storms, which may last from 1 to 6 days and which peak in early spring and mid-summer, enhance the energy of the surf zones (Merlotto and Bértola 2009).

Inlet channel: A sandy-muddy bottom characterizes the channel $(6 \mathrm{~km}$ long, $200 \mathrm{~m}$ wide and 0.8 to $3.0 \mathrm{~m}$ in depth) and extends from the mouth to a bridge (about $5 \mathrm{~km}$ upstream) built at the head of the inlet, which induced a large shoaling of this area. 

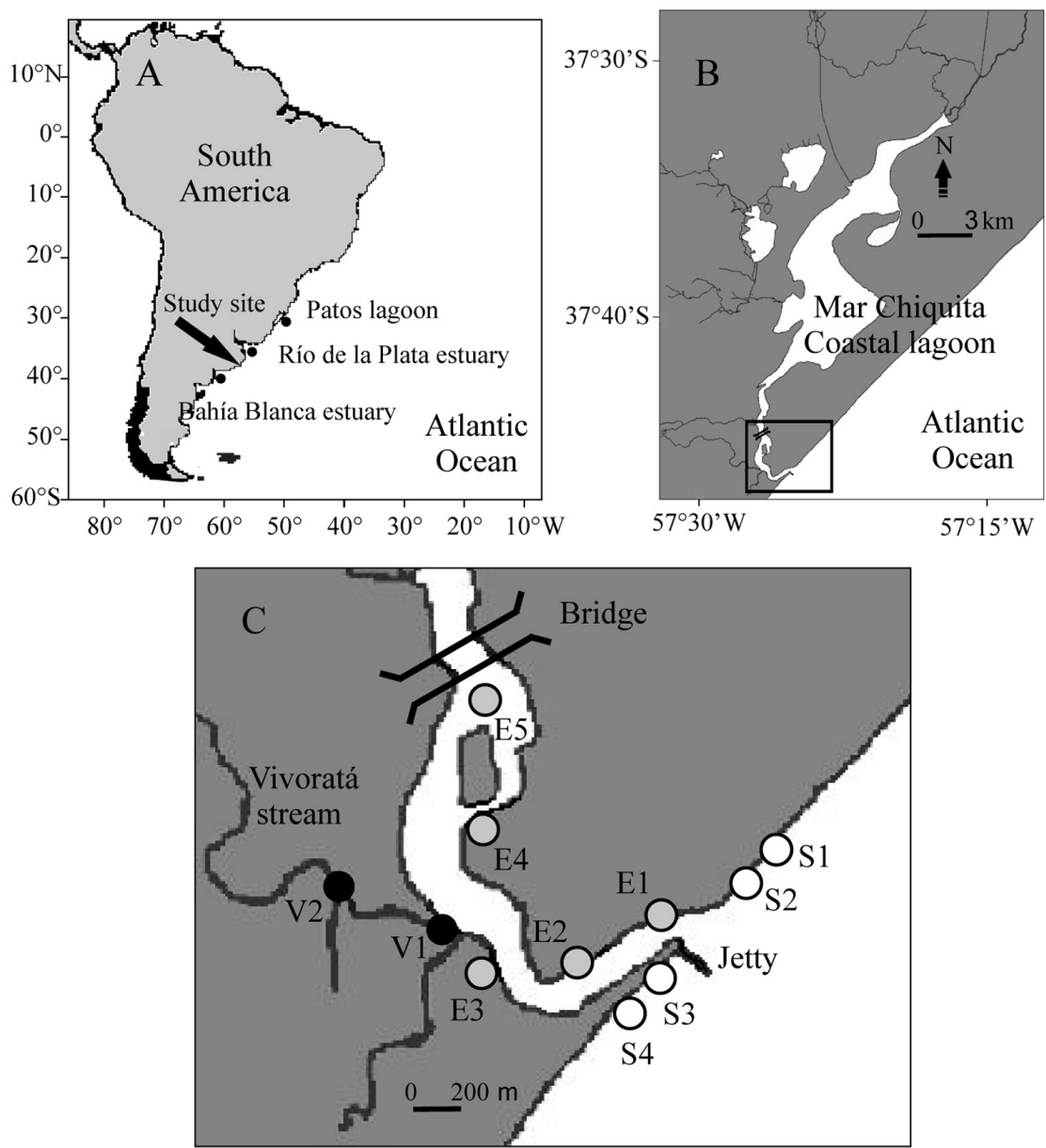

Fig. 1. - Map of the study site. A, location of Mar Chiquita coastal lagoon (Argentina) in South America and the main nearby estuarine systems; B, the area of Mar Chiquita coastal lagoon under study; and C, location of the sampling stations in the surf zone (S1-S4), the estuary zone (E1-E5) and the Vivoratá stream (V1-V2).

Tidal effect is only perceived up to the bridge (Reta et al. 2001). Temperature and salinity are extremely variable (González-Castro et al. 2009, Cousseau et al. 2011). Intrusion of the saline wedge varies according to tidal cycles and the wind direction. Strong winds from the sea (SW, S, SE, E) force the marine waters to enter the lagoon several kilometres from the mouth, while strong continental winds (NE, N, NW, W) aid the fast discharge of the lagoon water into the sea (Reta et al. 2001).

Vivoratá stream: Mar Chiquita lagoon receives the discharges of several freshwater canals and streams, with the Vivoratá stream being one of the largest and the only one which reaches the inlet channel (Reta et al. 2001). The portion of this stream under study is characterized by a muddy bottom and the water level oscillates in phase with that of the lagoon. Salinity fluctuates over a wide range depending on rainfall and/ or salt water intrusions.

\section{Biological and environmental sampling}

We focus on the spring-summer period because YOY fishes are more abundant in these seasons in temperate estuaries (e.g. Blaber and Blaber 1980, Potter et al. 1990, Martino and Able 2003, Cousseau et al. 2001). Juveniles were collected every 15 days from September 2009 to April 2010. Samples were taken at 11 stations covering the marine-estuarine gradient, including four stations in the surf zone adjacent to the lagoon's mouth (S1-S4), five stations in the estuary zone (E1-E5) and two stations in the Vivoratá stream, one at the mouth (V1) and the other $900 \mathrm{~m}$ upstream (V2) (Fig. 1). Sampling was performed in duplicate (each duplicate was averaged for statistical analysis) during daytime using a $4 \mathrm{~m}$ long, $1 \mathrm{~m}$ height nylon beach seine net with a $5 \mathrm{~mm}$ stretch mesh size and a $2 \mathrm{~m}$ cod-end. The net was pulled against the current for $50 \mathrm{~m}$ parallel to shoreline at $\sim 1 \mathrm{~m}$ depth, covering an area of about $200 \mathrm{~m}^{2}$. Each month, samples were taken at ebb and flood tides at all stations except S1 and S2, which could not be sampled on the ebb tide of April due to weather conditions. Fishes were fixed and preserved in $4 \%$ buffered formalin-seawater solution, and transported to the laboratory for identification, sorting, counting and measurement (Total length: TL). In highly abundant samples a representative sub-sample of 30 individuals was measured and the rest were counted.

Water temperature $\left({ }^{\circ} \mathrm{C}\right)$, salinity and transparency $(\mathrm{cm})$ were recorded with a hand thermometer, a Hydrobios refractometer and a Secchi disc, respectively. Wave period (seconds between consecutive waves) 
was also recorded in the surf zone. Average wind speed, mode wind direction and total amount rainfall during the sampling day plus the five previous days, were incorporated in the statistical analysis. Those data were provided by the National Weather Service (Servicio Meteorológico Nacional, Argentina).

\section{Environmental data and fish assemblage analysis}

A two-way PERMANOVA using Bray-Curtis distances with 10000 permutations of matrix data (Anderson 2001) was used to test the null hypothesis of no differences in temperature, salinity and transparency among sites (sampling stations), tidal stage (ebb, flood) and their interactions. Significant results were investigated using a posteriori one-way PERMANOVA.

Cluster analysis (CA) using Bray/Curtis dissimilarity measure and group average sorting (Krebs 1989) and an associated Similarity Profiles (SIMPROF) permutation test (Clarke et al. 2008) were employed to assess for temporal and spatial variations in juvenile fish abundance by both species and sampling stations. This combination of routines provides a sound statistical basis for identifying those points in the clustering procedure at which further subdivision of samples is unwarranted (Clarke et al. 2008). The null hypothesis of no significant differences among groups of sampling stations and of species was rejected if the significance level (p) was <0.01. Species abundances were log transformed [i.e. $\log (\mathrm{x}+1)]$, and those species with less than $5 \%$ average occurrence frequency were omitted in order to reduce the effects of rare species in the analysis. Similarity percentages (SIMPER) were used to determine which species were most responsible for the Bray-Curtis dissimilarity between groups defined by the CA-SIMPROF.

Canonical correspondence analysis (CCA) and partial CCA, direct gradient analysis techniques, were used to detect spatial-temporal patterns of variation in fish assemblages from measured environmental parameters (ter Braak and Verdonschot 1995). CCA was chosen because it assumes unimodal relationships between dependent and independent variables when the length of the first factorial axis obtained by detrended correspondence analysis (DCA) is greater than three standard deviations (Lepš and Smilauer 2003). The biological variables were $\log (\mathrm{x}+1)$ transformed species abundances (only species with more than $5 \%$ average occurrence frequency were used). The environmental variables were water temperature $\left({ }^{\circ} \mathrm{C}\right)$, salinity, transparency $(\mathrm{cm})$, monthly rainfall $(\mathrm{mm})$, wind speed $\left(\mathrm{m} \mathrm{s}^{-1}\right)$, wind direction, and tidal stage $($ flood $=+1 ; e b b=0)$. Since wind direction is a circular variable, it was transformed into a linear variable by using the cosine of the angle that the wind made on two orthogonal axes aligned perpendicular and parallel to the shoreline (Clark et al. 1996, Beyst et al. 2001). Onshore winds (SW, S, SE, E) were considered positive $(+1)$, while offshore winds (NE, N, NW, W) were considered negative $(-1)$.

Because temporal variation can show multi-collinearity across spatial scales, there can be a degree of redundancy in the variation explained by temporal and spatial variables (Peres-Neto 2006). To account for this potential redundancy, we used a seven-step analysis using CCA and partial CCA (i.e. CCA with covariables) to partition into different components the variation in fish abundance explained by independent variables (Lira-Noriega et al. 2007, Borcard et al. 2011). We first ran a CCA with all environmental variables (previously, non-correlation of the continuous explanatory variables was verified according to Lira-Noriega et al. 2007) and a forward selection combined with a permutation test (Blanchet et al. 2008) was used to select those variables that explained additional variance $(\mathrm{p}<0.05)$ in the CCA axes (Lira-Noriega et al. 2007, Borcard et al. 2011). The significant variables were retained for use in a partial CCA, in which seven different CCAs were applied on the species abundances. In each analysis, a different set of explanatory variables was used and the total sum of all canonical eigenvalues of each CCA was used to calculate the (pure) effect of the significant variables retained, the pure seasonal effect, the pure spatial effect, the shared information and the residual information (Lira-Noriega et al. 2007). Variance inflation factors (VIFs) were calculated to assess for collinearity between all variables. The significance $(\mathrm{p}<0.05)$ of the canonical axes and of the variation explained by each variable in the pCCA was tested with a Monte Carlo permutation test $(n=1000)$.

Finally, Spearman's correlations were run to examine general relationships between wave period (not included in CCAs) and abundance of fish species collected in the surf zone.

All statistical analyses were performed using $\mathrm{R}$ software (R Development Core Team 2012).

\section{RESULTS}

\section{Physical environment}

A two-way PERMANOVA revealed significant differences $(p($ perm $)<0.05)$ in water salinity and transparency among sampling stations but not between tidal stages (Table 1). Although no significant differences were observed in water temperature either among sampling stations or tidal stages, it matched seasonal trends with lower average values in September $\left(12 \pm 0^{\circ} \mathrm{C}\right)$ and higher ones in February $\left(22.05 \pm 1.7^{\circ} \mathrm{C}\right)$ (Fig. 2A).

Salinity varied from typical marine water in the surf zone (>30) to brackish water in the estuary (13-34) and the Vivoratá stream (7-34). Salinity values recorded in the surf zone (S1-S4) were higher than those recorded at the two innermost stations of the estuary zone (E4 and E5) and the Vivoratá stream (V1 and V2) (Fig. 2B). The innermost sampling station of the Vivoratá stream (V2) showed the lowest values (mean=18.63; median=20, $\min =7$ ) and was significantly different from all other stations (Fig. 2B).

Water transparency also reflected a spatial gradient with lower values in the surf zone, reflecting a more turbulent environment due to wave action and higher in the estuary zone with calmer conditions (Fig. 2C). Transparency recorded at sampling stations E1 and 
Table 1. - Summary results from the two-way PERMANOVA testing for differences in water temperature, salinity and transparency by sites, tides and their interaction. Mean Sq., mean square; df, degrees of freedom. * $\mathrm{p}<0.05, * * * \mathrm{p}<0.001$.

\begin{tabular}{llcccl}
\hline Parameter & Source & df & Mean Sq. & Pseudo F & p(perm) \\
\hline Temperature & Site (A) & 10 & 0.0013 & 0.0784 & 0.9999 \\
& Tide (B) & 1 & 0.0211 & 1.2585 & 0.2631 \\
& A×B & 10 & 0.0005 & 0.0249 & 0.9999 \\
& Residuals & 152 & 0.0168 & & \\
& Total & 173 & & & \\
Salinity & Site (A) & 10 & 0.1194 & 10.5037 & $1.00 \mathrm{E}-04^{* * *}$ \\
& Tide (B) & 1 & 0.0167 & 1.4648 & 0.2258 \\
& A×B & 10 & 0.0112 & 0.9832 & 0.4669 \\
& Residuals & 152 & 0.0114 & & \\
& Total & 173 & & & \\
Transparency & Site (A) & 10 & 0.0588 & 1.9612 & $0.0313^{*}$ \\
& Tide (B) & 1 & 0.0182 & 0.6059 & 0.4628 \\
& A $\times$ B & 10 & 0.0165 & 0.5514 & 0.8935 \\
& Residuals & 152 & 0.031 & & \\
& Total & 173 & & & \\
\hline
\end{tabular}

E5 was significantly higher than those recorded at all sampling stations of the surf zone. Also, transparency recorded at E1 was significantly higher than that recorded at V2 (Fig. 2C).

Rainfall was more abundant in March (145.6 mm) and less abundant in October (42.3 mm) (Fig. 3A).
Strong ( $>10 \mathrm{~m} \mathrm{~s}^{-1}$ ) southerly winds were dominant in September [Frequency $(F)=38.71 \%)$ ] (Fig. 3B), while strong northerly winds were dominant in October $(\mathrm{F}=35.48 \%)$ (Fig. 3C), November $(\mathrm{F}=22.58 \%)$ (Fig. 3D), March ( $\mathrm{F}=29.03 \%$ ) (Fig. 3H) and April $(\mathrm{F}=29 \%)$ (Fig. 3I). On the other hand, strong easterly winds were dominant in December $(\mathrm{F}=32.26 \%)$ (Fig. 3E), January $(\mathrm{F}=32.26 \%)$ (Fig. 3F), and February $(\mathrm{F}=35.71 \%)$ (Fig. 3G).

\section{Juvenile fish composition and spatial-temporal variations}

A total of 22240 individuals belonging to 22 species were collected during the study period (Table 2). Catches were dominated by YOY of most species, based on fish lengths examined (Table 2). However, small-sized species such as Platanichthys platana, Ramnogaster arcuata and Jenynsia multidentata (Whitehead 1985, Rosso 2006) were likely represented by both juvenile and adult stages.

The species were of marine origin, except for a few species of freshwater origin, namely $J$. multidentata, Oligosarcus jenynsii, Pimelodella laticeps and Rhamdia quelen. Odontesthes argentinensis was the most
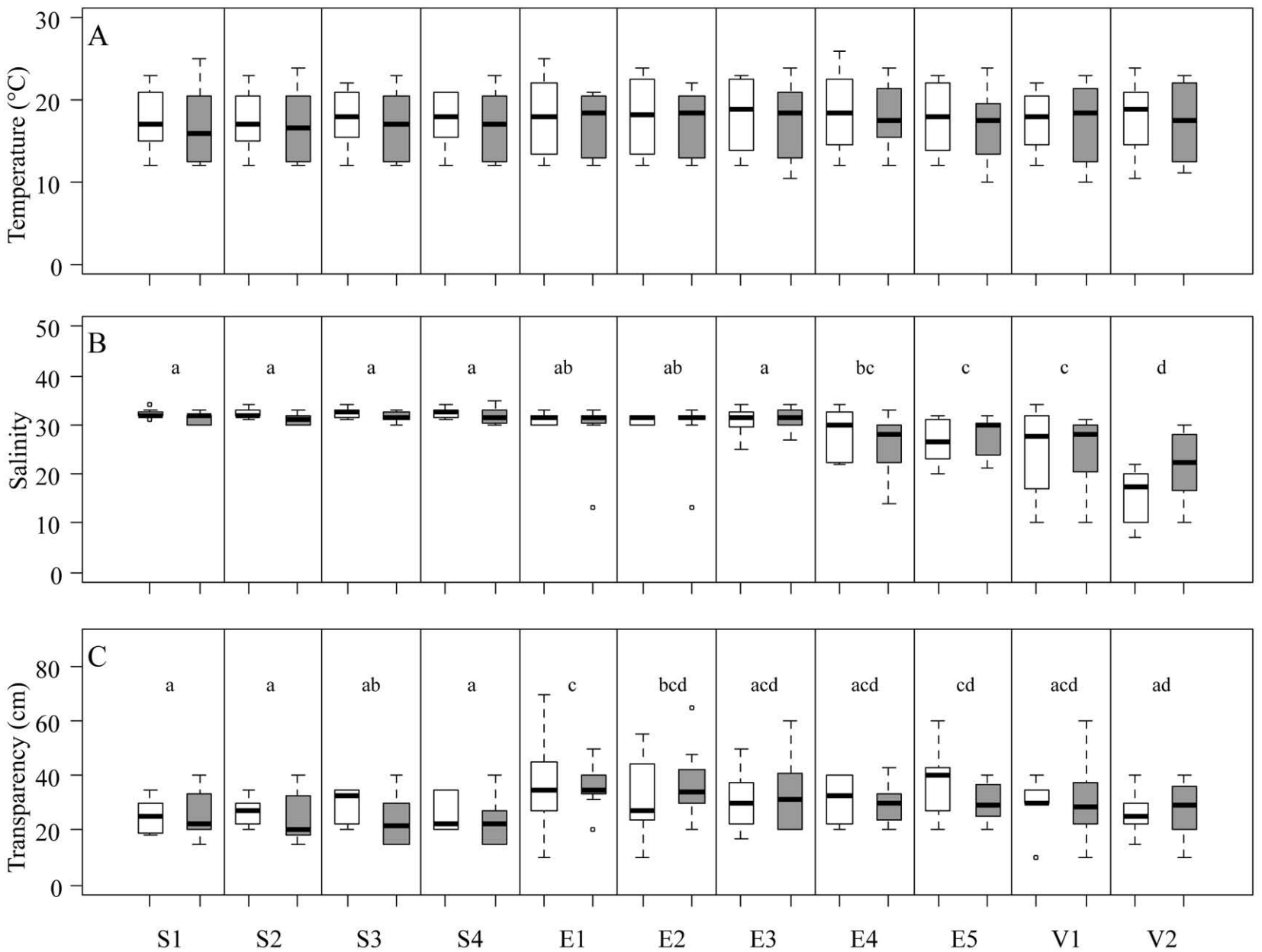

Fig. 2. - Spatial variation in water temperature (A), water salinity (B) and water transparency (C) (Secchi depth) along the marine-estuarine gradient in Mar Chiquita coastal lagoon at ebb (white boxes) and flood (grey boxes) (line, median; box, 25th to 75th percentiles; whiskers, minimum to maximum value range). Different letters denote significant differences between sampling stations without considering tidal stage. 


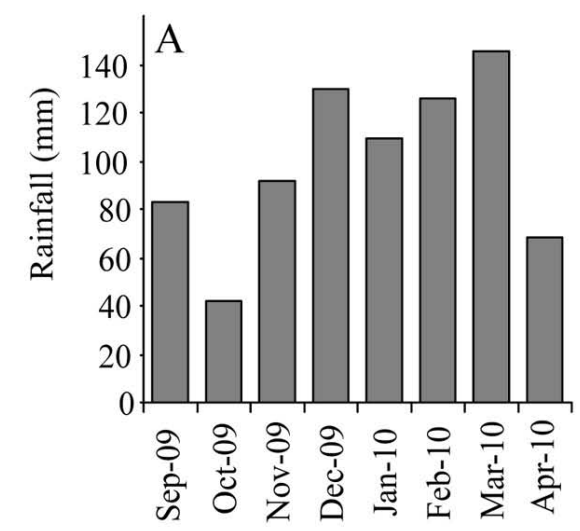

D

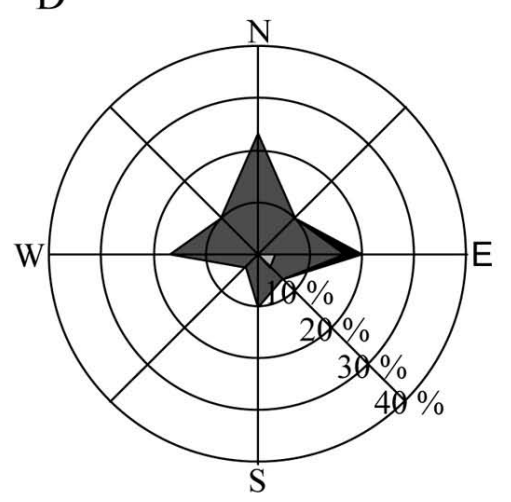

G

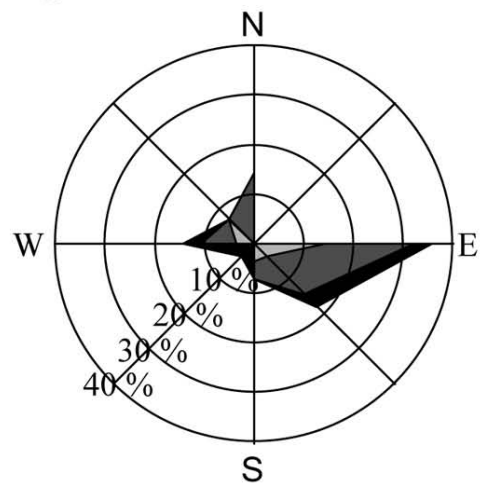

B

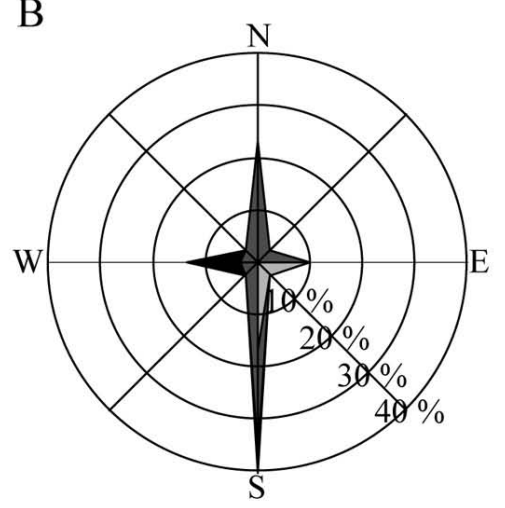

E

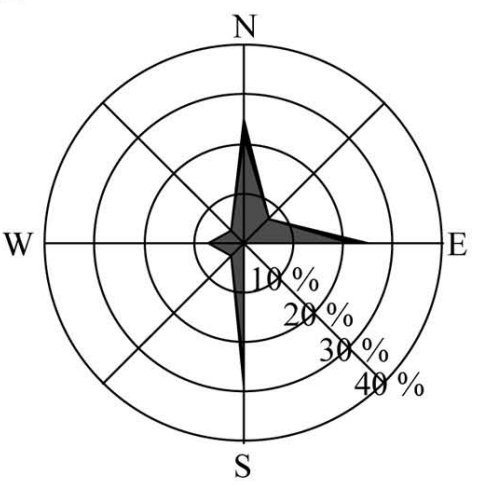

$\mathrm{H}$

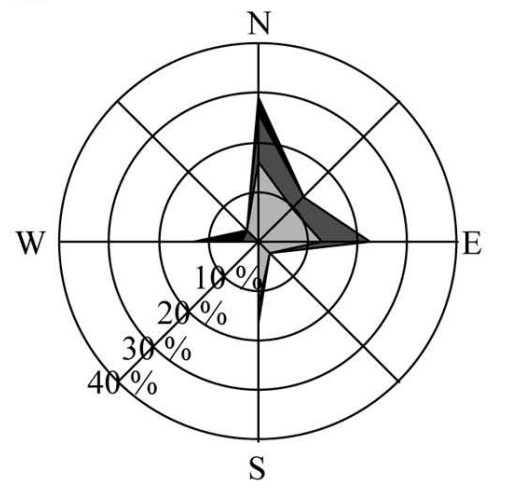

$\mathrm{C}$

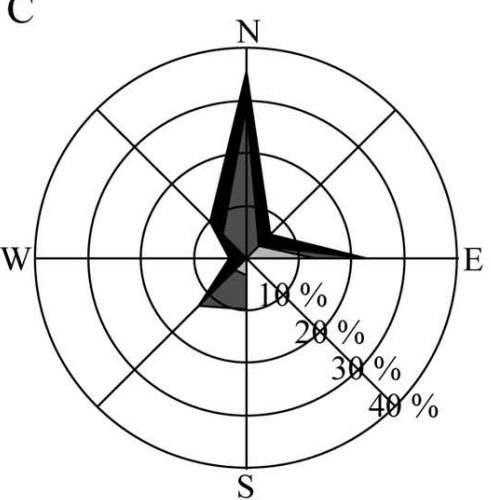

F

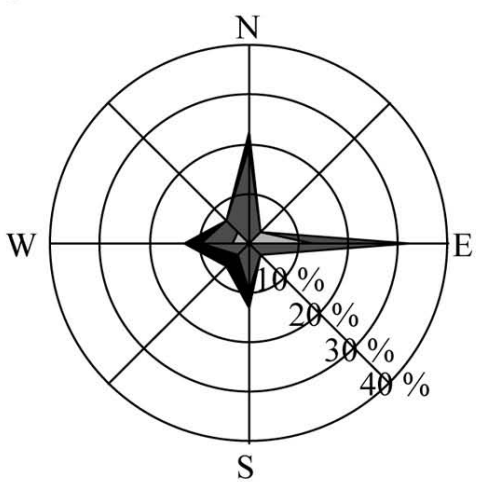

I

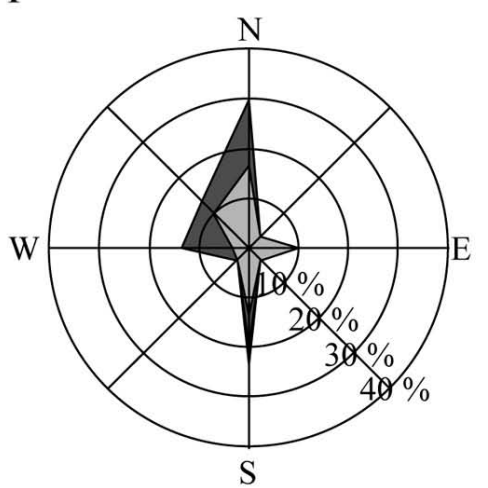

$\square<5 \square 5-9 \square 10-15 \square>15 \quad \mathrm{~m} \cdot \mathrm{s}^{-1}$

Fig. 3. - Temporal variation of rainfall amount (A), and of wind direction and speed for September 2009 (B), October 2009 (C), November 2009 (D), December 2009 (E), January 2010 (F), February 2010 (G), March 2010 (H) and April 2010 (I).

frequent species in the three zones (Table 2). However, $P$. platana was the most abundant species in the surf zone and the estuary zone, while Brevoortia aurea was the most abundant species in the Vivoratá stream (Table 2).

The CA and SIMPROF procedures, carried out using the log-transformed abundance of each fish species at each of the 174 sampling stations, demonstrated four significantly different groups (I to IV, Fig. 4). Group I was constituted by sampling stations of spring (September to November) from the estuary and the Vivoratá stream. Group II was constituted by sampling stations of spring-early summer (September to January) from the surf zone. Group III was constituted by sampling stations of early summer (December and January) from the estuary and the Vivoratá stream, and Group IV was constituted by sampling stations of late summer-early autumn (February to April) from the three zones. Group I was characterized by cooler temperatures $\left(12-19^{\circ} \mathrm{C}\right)$ than Group III $\left(19-25^{\circ} \mathrm{C}\right)$; rainfall was even in the two groups (217 and $238.2 \mathrm{~mm}$, respectively); and northerly winds were dominant in Group I while easterly winds were dominant in Group III. Group II was characterized by the combination of the factors described 
Table 2. - Abbreviation (Abr.), abundance $(\% \mathrm{~N})$, frequency $(\% \mathrm{~F})$ and total length $(\mathrm{TL})$ range $(\mathrm{mm})$ of fish species collected in the marineestuarine gradient of Mar Chiquita lagoon between September 2009 and April 2010.

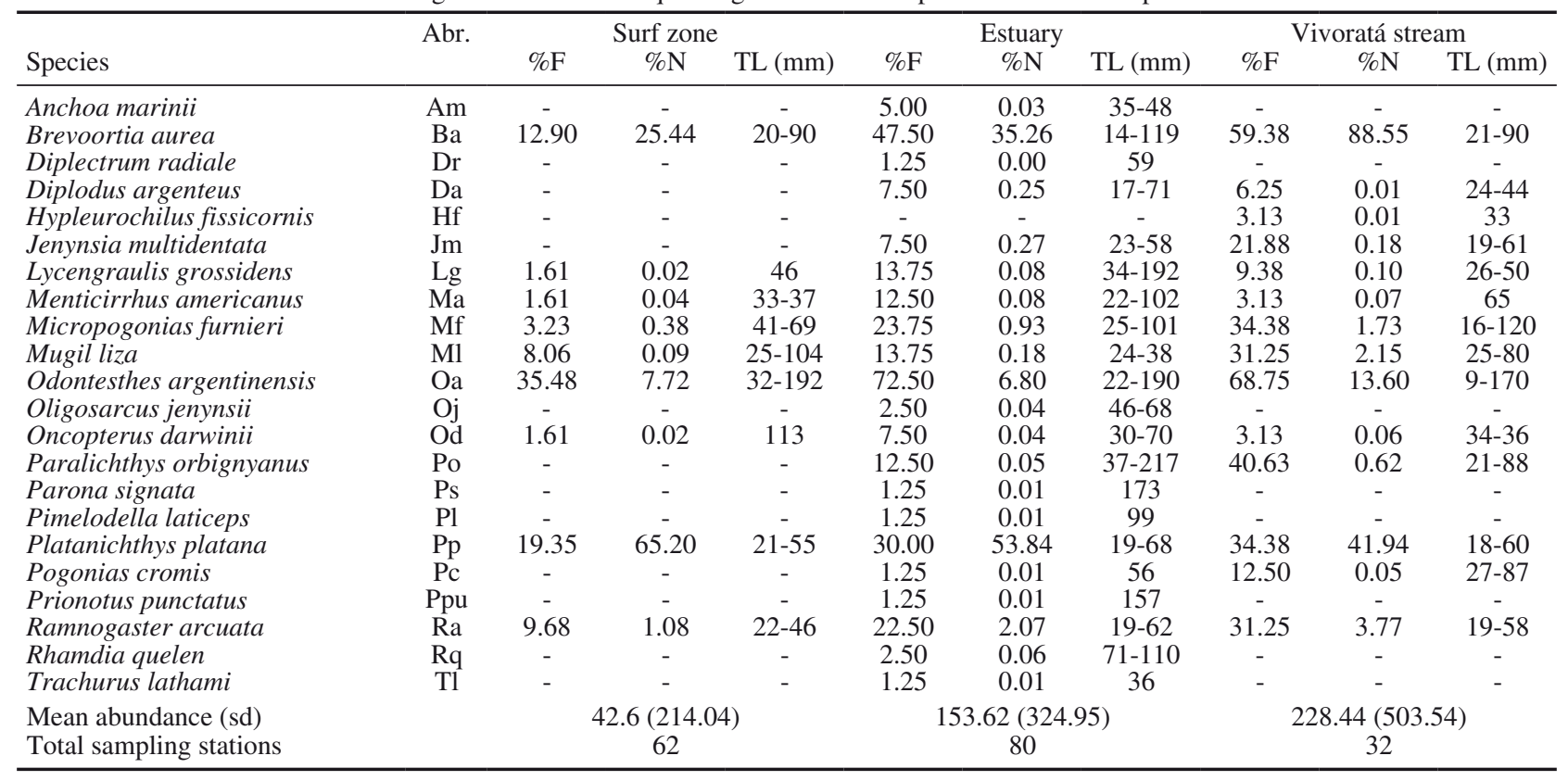

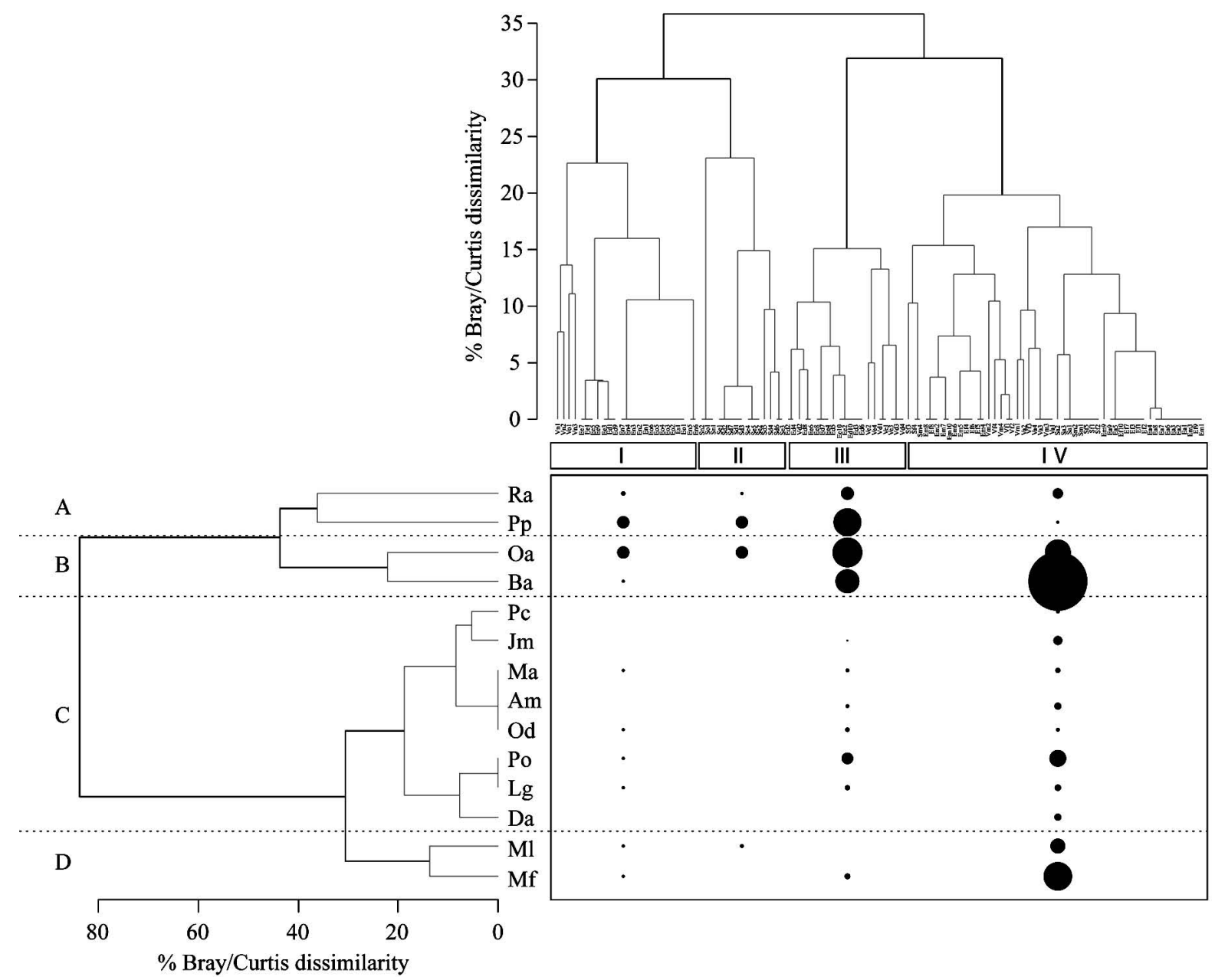

Fig. 4. - Dendrogram derived from subjecting fish species abundances to cluster and SIMPROF using the Bray/Curtis dissimilarity measure and group average sorting. Groups of samples marked by light grey lines are those which do not contain significant internal structure and thus represent fish groups. Group I, spring months in the estuary and the Vivoratá stream; Group II, spring-early summer months in the surf zone; Group III, early summer months in the estuary and the Vivoratá stream; Group IV, late summer-early autumn months in the three zones. Symbol size is proportional to the abundance of each taxon in each group of stations. See Table 2 for species abbreviations. 
Table 3. - Species contribution (\%) to the dissimilarity within groups defined by cluster analysis (CA) in the marine-estuarine gradient of Mar Chiquita lagoon. Groups: I, spring-estuary-Vivoratá; II, spring-early summer-surf zone; III, early summer-estuary-Vivoratá; IV, late

\begin{tabular}{|c|c|c|c|c|c|c|}
\hline & I vs. II & I vs. III & I vs. IV & II vs. III & II vs. IV & III vs. IV \\
\hline Average dissimilarity (\%) & 62.29 & 73.39 & 79.12 & 70.84 & 82.09 & 67.18 \\
\hline A. marinii & - & 0.17 & 0.58 & 0.18 & 0.56 & 0.43 \\
\hline B. aurea & 3.44 & 25.37 & 31.3 & 26.78 & 30.42 & 18.53 \\
\hline D. argenteus & - & - & 1.39 & - & 1.32 & 0.94 \\
\hline J. multidentata & - & 0.35 & 3.22 & 0.36 & 3.08 & 2.02 \\
\hline L. grossidens & 1.27 & 0.84 & 1.66 & 0.56 & 1.13 & 1.09 \\
\hline M. americanus & 0.36 & 0.61 & 1.11 & 0.52 & 0.92 & 0.93 \\
\hline M. furnieri & 0.72 & 0.44 & 11.65 & 0.22 & 11.15 & 6.39 \\
\hline M. liza & 4.89 & 0.82 & 6.13 & 0.51 & 5.45 & 3.08 \\
\hline O. argentinensis & 34.68 & 20.92 & 17.59 & 21.81 & 18.41 & 15.05 \\
\hline O. darwinii & 1.81 & 0.84 & 0.93 & 0.49 & 0.16 & 0.48 \\
\hline P. orbignyanus & 0.67 & 1.02 & 4.53 & 0.93 & 4.25 & 2.89 \\
\hline P. platana & 41.68 & 35.98 & 13.56 & 34.78 & 16.52 & 37.02 \\
\hline P. cromis & - & - & 0.46 & - & 0.44 & 0.29 \\
\hline R. arcuata & 10.46 & 12.64 & 5.91 & 12.86 & 6.21 & 10.85 \\
\hline
\end{tabular}

Table 4. - Results of canonical correspondence analysis (CCA) on all samples, inter-set correlations of environmental variables with CCA axes and variance inflation factors (VIFs) for the significant explanatory variables. Cum. constrained (\%), cumulative constrained percentage; Sp-env. correlations, species-environmental variable correlations; Sum unconstr. axes, sum of all unconstrained axes; Sum canonical axes, sum of all canonical axes.

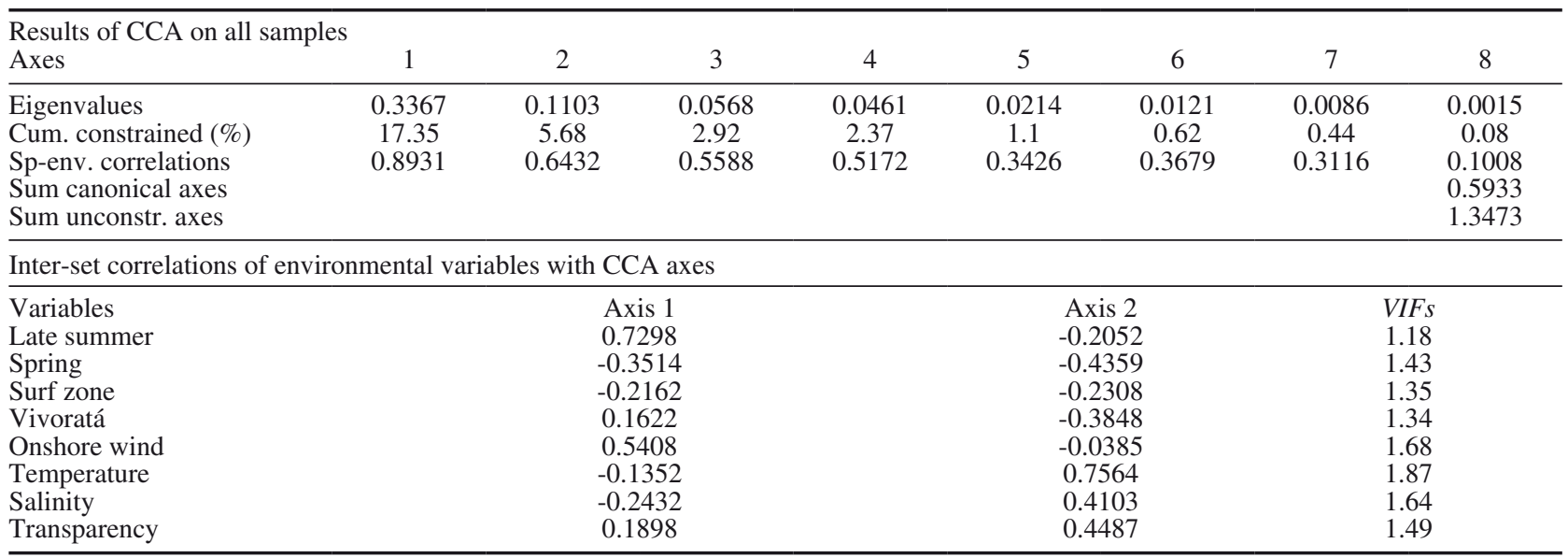

for Groups I and III. On the other hand, Group IV was characterized by warmer temperatures $\left(12-26^{\circ} \mathrm{C}\right)$, less rainfall $(340.15 \mathrm{~mm})$ and easterly (onshore) winds.

Four fish assemblages (A to D) were defined by the CA and SIMPROF procedures (Fig. 4). Fish assemblages A ( $R$. arcuata and $P$. platana) and $\mathrm{B}(O$. argentinensis and $B$. aurea) were mostly responsible for the differences between groups of stations (SIMPER contribution $>62 \%$; Table 3 ). During spring and early summer, $R$. arcuata, $P$. platana and $O$. argentinensis were more abundant in the surf zone (Group II) and in the estuary and Vivoratá stream (Groups I and III) (Fig. 4). Brevoortia aurea, on the other hand, was dominant during the late summer-early autumn period in all three zones sampled (Fig. 4). Species from fish assemblages C (Pogonias cromis, J. multidentata, Menticirrhus americanus, Anchoa marinii, Oncopterus darwinii, Paralichthys orbignyanus, Lycengraulis grossidens, Diplodus argenteus) and D (Mugil liza and Micropogonias furnieri) were more abundant in late summer-early autumn (Group IV) than in spring and early summer (Groups I to III) although with less contribution in the significant differences among groups (Table 3).

\section{Fish composition related to environmental variables}

CCA using seasons and zones as factors and temperature, salinity, transparency and wind effect as environmental variables explained $30.57 \%$ of the variation in fish abundance during the study period (Table 4). Tidal effect, rainfall and wind speed were not included in the CCA analysis because they showed no significant contribution to the model according to the forward selection procedure. The ordination diagram shows two gradients (Fig. 5). The first gradient corresponds to seasonal variations contrasting sampling stations belonging to late summer-early autumn associated with "onshore winds" on the right, and to spring and early summer associated with "offshore winds" on the left (Fig. 5). On the other hand, the second gradient corresponds to spatial variations contrasting sampling stations of the estuary associated with warmer, saltier and more transparent waters on the top, and of the surf zone and the Vivorata stream associated with the opposite conditions on the bottom (Fig. 5). Abundance of juvenile fishes was strongly associated with these gradients. Ten of the fourteen species incorporated in the analysis 


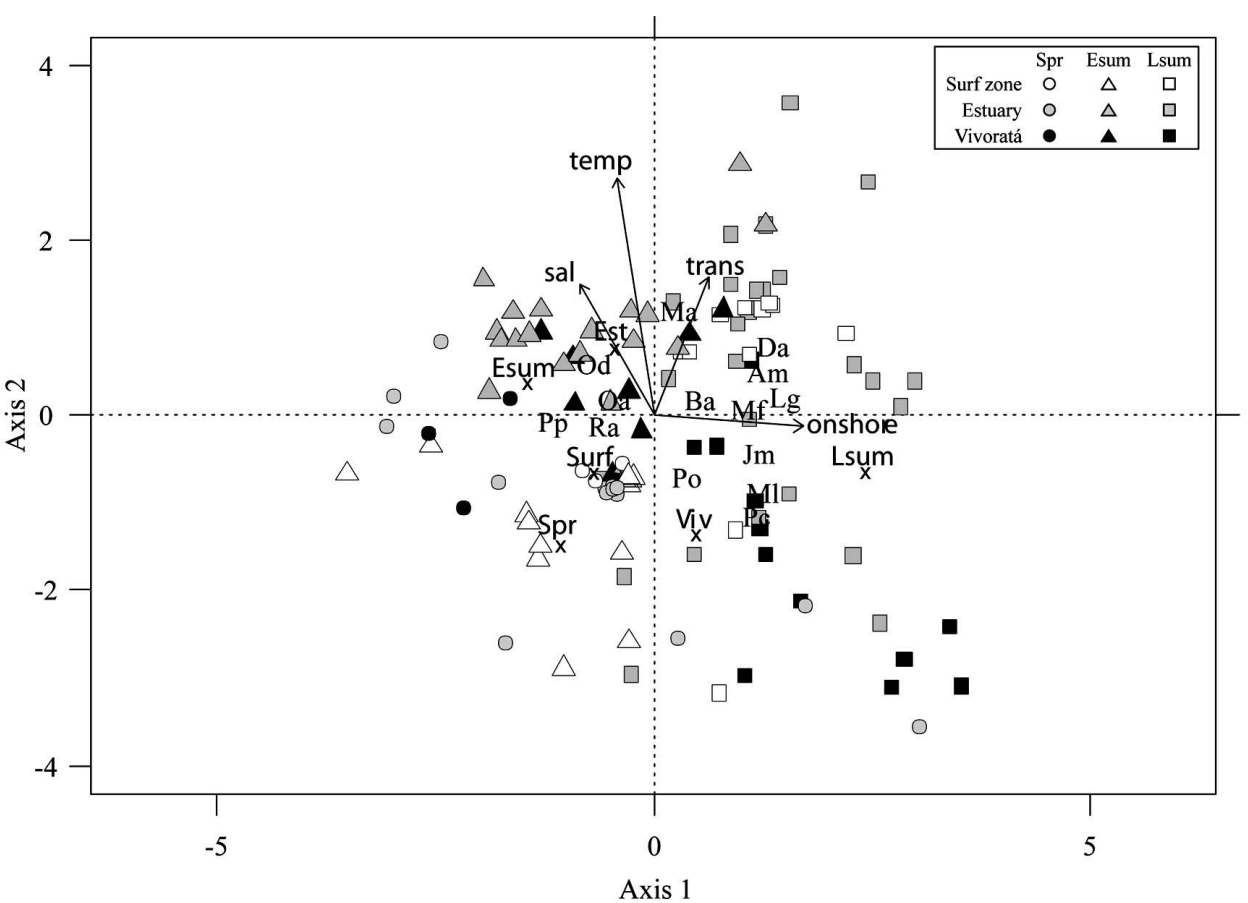

Fig. 5. - Ordination diagram (triplot) of the CCA. Temporal and spatial factors are indicated by crosses and environmental variables are indicated by arrows. Abbreviations are as follow: Spr, spring months; Esum, early summer months; Lsum, late summer-early autumn months; Surf, surf zone; Est, estuary; Viv, Vivoratá stream; temp, temperature; sal, salinity; trans, transparency; onshore, onshore winds. See Table 2 for species abbreviations.

Table 5. - Results of the partial CCA and variance decomposition showing the effects of Season, Zone and "Others" explanatory variables (onshore wind, temperature, salinity and transparency). Components A, B and C are equal to the explained variances in steps 5, 6 and 7, respectively. $\mathrm{D}$ is equal to the variance in step 4 minus the variance in step 7 , and $\mathrm{E}$ is calculated as total inertia minus the explained inertia in step 1 .

\begin{tabular}{llcc}
\hline $\begin{array}{l}\text { Results of the partial CCA } \\
\text { Step }\end{array}$ & Explanatory variables & Inertia & $\%$ \\
\hline 1 & Season+Zone+Others & 0.5933 & 30.57 \\
2 & Season & 0.3418 & 17.61 \\
3 & Zone & 0.1015 & 5.23 \\
4 & Others & 0.2433 & 12.54 \\
5 & Season with Zone and others as covariable & 0.2941 & 15.15 \\
6 & Zone with Season and others as covariable & 0.0552 & 2.85 \\
7 & Others with Season and Zone as covariable & 0.1573 & 8.11 \\
\hline Variance decomposition & & & $\%$ \\
Component & Source & Inertia & \\
\hline A & Pure Season & 0.2941 & 15.15 \\
B & Pure Zone & 0.0552 & 2.85 \\
C & Pure others & 0.1573 & 8.11 \\
D & Shared (4-7) & 0.086 & 4.43 \\
E & Residual & 1.3474 & 69.43 \\
\hline
\end{tabular}

were associated with the late summer-early autumn period and with onshore winds. Of these ten species, A. marinii, B. aurea, D. argenteus, L. grossidens, $M$. americanus and $M$. furnieri were also associated with the estuary and more transparent waters in the top-left of the diagram, while J. multidentata, M. liza, P. orbignyanus and $P$. cromis were associated with the Vivoratá stream and lower water temperature and salinity (Fig. 5). Two (O. argentinensis and O.darwinii) of the remaining four species were associated with the early summer period, the estuary and warmer and saltier conditions, whereas $P$. platana and $R$. arcuata were associated with the spring period, the surf zone and less transparent water conditions (Fig. 5).

Using partial CCAs, we estimated that the contribution of the pure seasonal effect $(15.15 \%$; sum of all canonical eigenvalues $=0.2941$ ) was almost five times higher than that of the pure spatial effect $(2.85 \%$; sum of all canonical eigenvalues $=0.0552$ ) and almost twice the pure retained environmental variables $(8.11 \%$; sum of all canonical eigenvalues $=0.1573)$ (Table 5). The remaining portion of variation $(4.43 \%)$ resulted from the intersection of the explanatory variables sets. VIF values of all explanatory variables were $<2$, showing non-collinearity (Table 4).

All the species of those collected in the surf zone except three showed a significant correlation with the wave period (Table 6). Relationships between the abundance of $B$. aurea, M. furnieri, M. liza, O. argentinensis, $P$. platana and $R$. arcuata were stronger with a longer wave period (more seconds between consecutive waves) while the abundance of $L$. grossidens, $M$. 
Table 6. - Spearman rank correlation coefficients $(\rho)$ between fish juvenile abundance and wave period (seconds between consecutive waves) of the species collected in the surf zone during the study period. $*(\mathrm{p}<0.05), * *(\mathrm{p}<0.01)$ and $* * *(\mathrm{p}<0.001)$ denote significant correlations.

\begin{tabular}{lccc}
\hline Species & $\rho$ & \multicolumn{2}{c}{$\mathrm{p}$-value } \\
\hline B. aurea & 0.6197 & 0.0009 & $* * *$ \\
L. grossidens & -0.0387 & 0.8479 & \\
M. americanus & 0.2969 & 0.1325 & \\
M. furnieri & 0.6609 & 0.0002 & $* * *$ \\
M. liza & 0.5939 & 0.0014 & $* *$ \\
O. argentinensis & 0.7053 & $3.98 \mathrm{E}-05$ & $* * *$ \\
$O$. darwinii & 0.2969 & 0.1325 & \\
$P$. platana & 0.4997 & 0.0079 & $* *$ \\
$R$. arcuata & 0.4639 & 0.0148 & $*$ \\
\hline
\end{tabular}

americanus and $O$. darwinii was not correlated with wave period (Table 6).

\section{DISCUSSION}

\section{Spatial and temporal variation in juvenile fish assemblages}

Our results revealed a higher number of fish species and also abundance in inner areas of Mar Chiquita than in the adjacent surf zone (Table 1). Several studies have demonstrated that surf zones may be used as nursery areas for early stages of fishes (e.g. Cowley et al. 2001, Strydom 2003, Watt-Pringle and Strydom 2003). However, examples of surf zones that are only used as a transient route from the sea to the estuary for some fish species have also been documented (e.g. Harris et al. 2001). For Mar Chiquita lagoon, a decline in fish larvae abundance and diversity in the surf zone compared with the adjacent sea and the estuary has recently been noted (Bruno et al. 2014) and is mainly attributed to the comparatively high wave energy of the surf zone. Moreover, data on juveniles sampled about 1 to $2.5 \mathrm{~km}$ off Mar Chiquita's inlet (J.M. Díaz de Astarloa and E. Mabragaña, unpublished data) showed a higher number of fish species as compared with our results in the surf zone with several species in common. These facts support the idea that the harshness of the surf zone may not be suitable for the residence of young fishes and, therefore, the surf zone adjacent to Mar Chiquita's inlet acts only as a transient corridor between the sea and the lagoon.

Nevertheless, after factoring out common spatialtemporal variation $(4.43 \%)$, our partitioning analysis showed that the temporal dimension (after controlling the variation related to spatial scale) had an almost five times greater contribution $(15.15 \%)$ than the spatial scale $(2.8 \%)$ to explaining variation in abundance of juvenile fishes recruiting to this shallow and micro-tidal choked lagoon. This same pattern has been observed in the recruitment of fishes into the Patos Lagoon Estuary (southern Brazil) (Garcia et al. 2012) which, despite the larger size area $\left(10360 \mathrm{~km}^{2}\right)$ compared with Mar Chiquita coastal lagoon $\left(46 \mathrm{~km}^{2}\right)$, has a very similar shape and host a common fish fauna (e.g. Cousseau et al. 2001, Garcia et al. 2003, González-Castro et al. 2009) with our system under study.

No distinctive fish assemblages for each of the zones have been observed, as also reported by Harris et al. (2001) in the ocean-estuarine gradient of the Northern KwaZulu-Natal Coast (South Africa) and by Martino and Able (2003) in the ocean-riverine gradient of the Mullica River-Great Bay estuary (USA). However, four groups of sampling stations were defined by the CA (Fig. 4), indicating differences in fish composition among zones during the spring-early summer period (Groups I to III) while the composition of juvenile fishes was homogeneous along the marine-estuarine gradient during the late summer-early autumn period (Group IV). Within the surf zone, it was observed that fish composition found during spring was similar to that found during early summer months (Fig. 4). The low abundance and diversity of fishes recorded in this area probably prevented us from detecting significant temporal differences in fish composition between spring and early summer.

The two fish assemblages that most contributed to the temporal differences (Table 3), were composed of four main species: $P$. platana and $R$. arcuata (Group A), and O. argentinensis and B. aurea (Group B) (Fig. 4). Different periods of recruitment of these species into the lagoon were observed. Platanichthys platana and $R$. arcuata reached first the Mar Chiquita marineestuarine system in spring, although with lower abundances than in early summer. $R$. arcuata occurs in coastal environments (Whitehead 1985), so immigration from the sea is expected. Conversely, $P$. platana has long been recognized as a fresh- and brackish-water species (Whitehead 1985) with an ongoing trend to be regarded as an estuarine resident and migrant (e.g. Plavan et al. 2010) and also as an inhabitant of coastal environments (Rosso 2006). Since previous studies in Mar Chiquita demonstrated lower abundances of this species in the inner areas of the lagoon (with oligohaline waters) than near to the mouth (González-Castro et al. 2009), further investigation is needed in order to elucidate the direction of movement of this species. However, the early ingress of these two Clupeids likely reflects a winter spawning period near Mar Chiquita's inlet area, which has only been reported for $R$. arcuata in the Río de la Plata estuary (Rodríguez et al. 2008).

Odontesthes argentinensis was also one of the first species to reach the Mar Chiquita system and similarly, to the two species mentioned above, its abundance was higher in the subsequent months. The reproductive season for this species extends from October to November (austral spring) on the Argentine coast (40$41^{\circ} \mathrm{S}$ ) (Llompart et al. 2013), and González-Castro et al. (2009) reported a broader period (from winter to spring months) of probable spawning activity within this lagoon. Although our sampling strategy does not allow us to estimate the fishes' direction of movement, the lack of spawning females of the most abundant marine species within Mar Chiquita (Cousseau et al. 2011, González-Castro et al. 2011) could indicate that most of the young fishes occurring in the lagoon should be spawned at sea. However, the early (spring months) ingress of $O$. argentinensis juveniles into the study area may be either from the sea or from inside the lagoon.

Juveniles of $B$. aurea were more abundant during summer and autumn in agreement with previous 
studies in the area (Cousseau et al. 2001, Bruno et al. 2013) and other similar estuarine systems in Argentina (Acha and Macchi 2000), Brazil (Muelbert and Weiss 1991) and Uruguay (Plavan et al. 2010). The late arrival of $B$. aurea to the Mar Chiquita system relies on a later onset of the reproductive season (late winter/ early summer) in the Argentine coast (Acha and Macchi 2000). In contrast to larvae of other clupeoids from the northern hemisphere (B. tyrannus and B. patronus) (Powell 1994) that are spawned offshore and then drift towards the coast, $B$. aurea larvae in the Río de la Plata estuary are spawned and retained in estuarine waters (Acha and Macchi 2000). In Mar Chiquita coastal lagoon ( $350 \mathrm{~km}$ southward of the Río de la Plata estuary) the occurrence of few individuals of $B$. aurea in advanced maturation (Cousseau et al. 2011) and the high abundances of eggs and larvae of this species over the inlet channel (Bruno et al. 2014) suggest that spawning activity may also occur inside this estuarine system. Nevertheless, the bulk of the spawning must be at sea given the dominance of post-flexion larvae on ichthyoplankton surveys conducted in the area (Bruno et al. 2014). Therefore, similarly to O. argentinensis, the juveniles of $B$. aurea found in our study could be spawned inside and/or outside Mar Chiquita, showing a flexible spawning strategy for this species.

The ingress of late larvae (post-flexion) and early juvenile fishes into temperate estuaries in high abundance in late summer is the most common recruitment pattern for those species which reproduce in sea waters within late spring-early summer (Potter et al. 2001). Micropogonias furnieri (Cousseau et al. 2001, Cousseau and Perrotta 2004, Bruno et al. 2013), P. orbignyanus (Cousseau et al. 2001) and M. liza (González-Castro et al. 2011), which comprised the remaining fish assemblages related to this season, fit with this reproductive strategy. These temporal peaks have also been reported in similar estuaries worldwide (Muelbert and Weiss 1991, Cowley et al. 2001) and it has been suggested that they tend to coincide with greater estuarine planktonic food sources and higher water temperatures (Dickey-Collas et al. 1996, Garcia et al. 2012).

\section{Juvenile fish assemblages and relationships with the environment}

Two major phases are recognized in the recruitment into estuaries by species spawned offshore. The first is the accumulation in the coastal zone; and the second is the aggregation near inlets and estuary mouths and eventual passage through them (Boehlert and Mundy 1988). Aggregations of estuarine associated young fishes in the inshore zone have been related to a number of environmental factors. Winds, tides, river runoff and alongshore currents are the main forces involved in migrations of larvae and juveniles (Boehlert and Mundy 1988).

Although there were clear gradients of water salinity and transparency throughout the study area (Fig. $2)$, neither these factors nor water temperature were as important in explaining the variability of the Mar Chiquita marine-estuarine system as was the wind direction (Fig. 5, Table 4), given that most of the species incorporated in the CCA were associated with "onshore winds". For instance, most species related to saltier conditions $(O$. argentinensis, $O$. darwinii) were those related to the estuary zone, while those related to lower salinity values (J. multidentata, M. liza, P. orbignyanus and $P$. cromis) were related to the Vivoratá stream (Fig. 5). Though salinity has been categorized as an important factor in detecting estuaries during the recruitment process of juveniles (Blaber and Blaber 1980, Martino and Able 2003), olfactory cues associated with riverine inputs, and hence estuarine outflow, stimulate the immigration of euryhaline fishes into estuaries and not salinity per se (Whitfield 1994).

On the other hand, most of the species related to warmer and transparent waters (A. marinii, B. aurea, $D$. argenteus, L. grossidens, $M$. americanus and $M$. furnieri) were those related to the estuary zone and to the late summer period. Conversely, the species related to cooler and less transparent waters ( $P$. platana and $R$. arcuata) were related to the spring period and the surf zone, which is characterized by a more turbulent environment due to wave action (Fig. 5). However, it was observed that most of the species collected in the surf zone were related to episodes of longer wave period (more seconds between waves; Table 6), which is an expected pattern as the transition through a less turbulent environment from the sea into the estuary requires a lower energy investment, especially in a life history stage when most surplus power needs to be allocated to growth (Miller et al. 1985).

To our knowledge, there are few studies dealing with larval and/or juvenile fish distribution in estuaries that include the wind effect on multivariate analysis as a potential variable to explain recruitment patterns. However, a few works on numerical models which couple biological and physical information to study fish and/or invertebrate larvae transport (e.g. Blanton et al. 1999, Epifanio and Garvine 2001, Martins et al. 2007) have explained that the transport of particles is controlled by wind action. Also, fish productivity inside estuarine systems (like the Patos Lagoon Estuary, Brazil) is highly dependent on the passage of weather fronts in spring when fish eggs are more abundant in the ocean (Martins et al. 2007). Moreover, previous studies have demonstrated that onshore winds are key issues in the success of fish larvae recruitment from offshore spawning grounds to inner areas of Mar Chiquita instead of tides (Bruno et al. 2014).

Therefore, because most fish species present in and off Mar Chiquita lagoon are both in larvae (Bruno et al. 2014) and juvenile stages, it may be argued that Mar Chiquita's inlet and the adjacent coastal marine waters form a broad nursery ground for fish larvae and juveniles, the surf zone adjacent to Mar Chiquita's inlet being only a transient corridor between the sea and the lagoon. Therefore, if reproduction takes place at sea near to Mar Chiquita's inlet, individuals may remain in the coastal area immediately offshore of the surf zone or enter the lagoon. These alternative nurseries may be highly beneficial for fish survival (and also to maximize surplus power, sensu Miller et al. 1985) 
in a system where fish recruitment depends on a relatively erratic forcing such as winds (though with some seasonal trends, Reta et al. 2001), instead of a highly predictable agent like tides.

Summarizing, the marine-estuarine gradient along the Mar Chiquita's inlet act as a broad nursery ground for juvenile fishes, although the surf zone between the lagoon and the sea is used as a corridor between the two environments rather than a place to stay. The differential timing of recruitment into this nursery ground by the dominant species may be related to specific differences in spawning periods. However, regardless of the period in which juvenile fishes reach this nursery ground, wind direction seems to be important in their orientation and transportation towards the Mar Chiquita's inlet. Several studies have established that the success of recruitment of juveniles into estuaries relies on vertical movements in order to take advantage of water flows between flood and ebb tides (e.g. Boehlert and Mundy 1988, Primo et al. 2013). We propose here that for very shallow and micro-tidal estuaries (like Mar Chiquita) wind could play an important role in the success of recruitment of juvenile fishes. Particularly, onshore winds may be determinant in both the accumulation of young fishes near the estuary's mouth and arrival at the inner areas of the estuary, where they will find more favourable conditions for survival.

\section{ACKNOWLEDGEMENTS}

We express our gratitude to Buenos Aires Province Ministry of Agrarian Subjects authorities, M. Iza and J. Mangiarotti (forest guard of the Mar Chiquita Biosphere Reserve) for sampling permission; to S.M. Delpiani, G.E. Blasina, J. Luca, A. Martinez and A. Márquez for field assistance; and to A.T. Gómez (National Weather Service, Argentina), who kindly provided rainfall and wind data. We also thank A. Grau for helpful revision of the grammar and style and the anonymous reviewers for their useful comments on an early draft. This study was supported by UNMdP-EXA 490/10 and UNMdPEXA $555 / 12$. D.O.B. was supported by fellowships from CONICET (Argentina). This is part of D.O.B's $\mathrm{PhD}$ thesis.

\section{REFERENCES}

Acha E.M., Macchi G.J. 2000. Spawning of Brazilian menhaden, Brevoortia aurea, in the Río de la Plata estuary off Argentina and Uruguay. Fish. Bull. 98: 227-235.

Amara R., Meziane T., Gilliers C., et al. 2007. Growth and condition indices in juvenile sole Solea solea measured to assess the quality of essential fish habitat. Mar. Ecol. Progr. Ser. 351: 201-208. http://dx.doi.org/10.3354/meps07154

Anderson M.J. 2001. A new method for non-parametric multivariate analysis of variance. Aus. Ecol. 26: 32-46. http://dx.doi.org/10.1111/j.1442-9993.2001.01070.pp.x

Bértola G. 2006. Morfodinámica de playas del sudeste de la Provincia de Buenos Aires (1983-2004). Lat. Am. J. Sedimentol. Basin. Anal. 13: 31-57.

Beyst B., Hostens K., Mees J. 2001. Factors influencing fish and macrocrustacean communities in the surf zone of sandy beaches in Belgium: temporal variation. J. Sea Res. 46: 281-294. http://dx.doi.org/10.1016/S1385-1101(01)00087-9

Blaber S.J.M., Blaber T.G. 1980. Factors affecting the distribution of juvenile estuarine and inshore fish. J. Fish Biol. 17: 143-162. http://dx.doi.org/10.1111/j.1095-8649.1980.tb02749.x

Blanchet F.G., Legendre P., Borcard D. 2008. Forward selection of explanatory variables. Ecology 89: 2623-2632. http://dx.doi.org/10.1890/07-0986.1

Blanton J.O., Werner F.E., Kalpolnai A., et al. 1999. Wind generated transport of fictitious passive larvae into shallow tidal estuaries. Fish. Oceanogr. 8: 210-223. http://dx.doi.org/10.1046/j.1365-2419.1999.00024.x

Boehlert G.W., Mundy B.C. 1988. Roles of behavioral and physical factors in larval and juvenile fish recruitment to estuarine nursery areas. Am. Fish. Soc. Symp. 3: 51-67.

Borcard D., Gillet F., Legendre P. 2011. Numerical Ecology with R. Springer, New York, 306 pp. http://dx.doi.org/10.1007/978-1-4419-7976-6

Bruno D.O., Barbini S.A. Díaz de Astarloa J.M., et al. 2013. Fish abundance and distribution patterns related to environmental factors in a choked temperate coastal lagoon (Argentina). Braz. J. Oceanogr. 61: 43-53 http://dx.doi.org/10.1590/S1679-87592013000100005

Bruno D.O., Delpiani, S.M., Cousseau, M.B., et al. 2014. Oceanestuarine connection for ichthyoplankton through the inlet channel of a temperate choked coastal lagoon (Argentina). Mar. Freshw. Res. 65: 1116-1130. http://dx.doi.org/10.1071/MF13128

Clark B.M., Bennett B.A., Lamberth S.J. 1996. Temporal variations in surf zone fish assemblages from False Bay, South Africa. Mar. Ecol. Prog. Ser. 131: 35-47. http://dx.doi.org/10.3354/meps131035

Clarke K.R., Somerfield P.J., Gorley R.N. 2008. Testing of null hypotheses in exploratory community analyses: similarity profiles and biota-environment linkage. J. Exp. Mar. Biol. Ecol. 366: 56-69. http://dx.doi.org/10.1016/j.jembe.2008.07.009

Cousseau M.B., Perrotta R.G. 2004. Peces marinos de Argentina. Biología, distribución, pesca. Publicaciones Especiales INIDEP, Mar del Plata, 167 pp.

Cousseau M.B., Díaz de Astarloa J.M., Figueroa D.E. 2001. La Ictiofauna de la Laguna Mar Chiquita. In: Iribarne O. (ed.), Reserva de Biósfera Mar Chiquita: Características físicas, biológicas y ecológicas. Editorial Martín, Mar del Plata, pp. 187-203.

Cousseau M.B., Marchesi M.C., Figueroa D.E., et al. 2011. Relación íctica entre la laguna costera Mar Chiquita y el mar adyacente. Hist. Nat. 1: 85-100.

Cowley P.D., Whitfield A.K., Bell K.N.I. 2001. The surf zone ichthyoplankton adjacent to an intermittently open estuary, with evidence of recruitment during marine overwash events. Estuar. Coast. Shelf Sci. 52: 339-348. http://dx.doi.org/10.1006/ecss.2000.0710

Dickey-Collas M., Gowen R.J., Fox C.J. 1996. Distribution of larval and juvenile fish in the western Irish Sea: relationship to phytoplankton, zooplankton biomass and recurrent physical features. Mar. Freshw. Res. 47: 169-181. http://dx.doi.org/10.1071/MF9960169

Epifanio C.E., Garvine R.W. 2001. Larval transport on the Atlantic continental shelf of North America: a review. Estuar. Coast. Shelf Sci. 52: 51-77. http://dx.doi.org/10.1006/ecss.2000.0727

Garcia A.M., Raseira M.B., Vieira J.P., et al. 2003. Spatiotemporal variation in shallow-water freshwater fish distribution and abundance in a large subtropical coastal lagoon. Environ. Biol. Fish. 68: 215-228 http://dx.doi.org/10.1023/A:1027366101945

Garcia A.M., Vieira J.P., Winemiller K.O., et al. 2012. Factoring scales of spatial and temporal variation in fish abundance in a subtropical estuary. Mar. Ecol. Progr. Ser. 461: 121-135. http:/dx.doi.org/10.3354/meps09798

González-Castro M., Díaz de Astarloa J.M., Cousseau M.B., et al. 2009. Fish composition in a south-western Atlantic temperate coastal lagoon: Spatial-temporal variation and relationships with environmental variables. J. Mar. Biol. Ass. U.K. 89: 593-604.

http://dx.doi.org/10.1017/S0025315409003002

González-Castro M., Macchi G.J., Cousseau M.B. 2011. Studies on reproduction of the mullet Mugil platanus Günther, 1880 (Actinopterygii, Mugilidae) from the Mar Chiquita coastal lagoon, Argentina: similarities and differences with related species. Italian J. Zool. 78: 343-353. http://dx.doi.org/10.1080/11250003.2010.549154

Harris S.A., Cyrus D.P., Beckley L.E. 2001. Horizontal trends in 
larval fish diversity and abundance along an ocean-estuarine gradient on the northern KwaZulu-Natal coast, South Africa. Estuar. Coast. Shelf Sci. 53: 221-235 http://dx.doi.org/10.1006/ecss.2001.0803

Krebs C.J. 1989. Ecological methodology. Addison and Wesley Longman, California, $620 \mathrm{pp}$.

Lepš J., Smilauer P. 2003. Multivariate analysis of ecological data using CANOCO. Cambridge University Press, New York, 269 pp. http://dx.doi.org/10.1017/CBO9780511615146

Lira-Noriega A., Laborde J., Guevara S., et al. 2007. Canonical correspondence analysis of lowland pasture vegetation in the humid tropics of Mexico. In: Zuur A.F., Ieno E.N., Smith G.M. (eds), Analysing Ecological Data. Springer, New York, pp. 561-574.

Llompart F.M, Colautti D.C., Maiztegui T., et al. 2013. Biological traits and growth patterns of pejerrey Odontesthes argentinensis. J. Fish Biol. 82: 458-474. http://dx.doi.org/10.1111/j.1095-8649.2012.03494.x

Martinetto P., Ribeiro P., Iribarne O. 2007. Changes in distribution and abundance of juvenile fishes in intertidal soft sediment areas dominated by the burrowing crab Chasmagnathus granulatus. Mar. Freshw. Res. 58: 194-203. http://dx.doi.org/10.1071/MF06079

Martino E.J., Able K.W. 2003. Fish assemblages across the marine to low salinity transition zone of a temperate estuary. Estuar. Coast. Shelf Sci. 56: 969-987. http://dx.doi.org/10.1016/S0272-7714(02)00305-0

Martins I.M., Dias J.M., Fernandes E.H., et al. 2007. Numerical modelling of fish eggs dispersion at the Patos lagoon estuary, Brazil. J. Mar. Syst. 68: 537-555. http://dx.doi.org/10.1016/j.jmarsys.2007.02.004

Merlotto A., Bértola G. 2009. Coastline evolution at Balneario Parque Mar Chiquita, Argentina. Cienc. Mar. 35: 271-286.

Miller J.M., Crowder L.B., Moser M.L. 1985. Migration and utilization of estuarine nurseries by juvenile fishes an evolutionary perspective. Contrib. Mar. Sci. 27: 338-352.

Muelbert J.H., Weiss G. 1991. Abundance and distribution of fish larvae in the channel area of the Patos Lagoon Estuary, Brazil. In: Hoyt R.D. (ed.), Larval fish recruitment in the Americas. Proceedings of the thirteenth annual fish conference. NOAA Technical Report NMFS 95, Merida, pp. 43-54.

Peres-Neto P.R. 2006. A unified strategy for estimating and controlling spatial, temporal and phylogenetic autocorrelation in ecological models. Oecol. Bras. 10: 105-119. http://dx.doi.org/10.4257/oeco.2006.1001.07

Plavan A.A., Passadore C., Gimenez C. 2010. Fish assemblage in a temperate estuary on the uruguayan coast: seasonal variation and environmental influence. Braz. J. Oceanogr. 58: 299-314.

Potter I.C., Beckley L.E., Whitfield A.K., et al. 1990. Comparisons between the roles played by estuaries in the life cycles of fishes in temperate Western Australia and Southern Africa. Environ. Biol. Fish. 28: 143-178. http://dx.doi.org/10.1007/BF00751033

Potter I.C., Bird D.J., Claridge P.N., et al. 2001. Fish fauna of the Severn Estuary. Are there long-term changes in abundance and species composition and are the recruitment patterns of the main marine species correlated? J. Exp. Mar. Biol. Ecol. 258: 15-37. http://dx.doi.org/10.1016/S0022-0981(00)00343-9

Powell A.B. 1994. Life history traits of two allopatric clupeids, Atlantic 567 menhaden and gulf menhaden, and the effects of har- vesting on these traits. North Am. J. Fish. Manage. 14: 53-64. http://dx.doi.org/10.1577/1548-8675(1994)014<0053:LHTOT $\mathrm{A}>2.3 . \mathrm{CO} ; 2$

Primo A.L., Azeiteiro U.M., Marques S.C., et al. 2013. Colonization and nursery habitat use patterns of larval and juvenile flatfish species in a small temperate estuary. J. Sea Res. 76: 126-134. http://dx.doi.org/10.1016/j.seares.2012.08.002

R Development Core Team 2012. R: A language and environment for statistical computing. R Foundation for Statistical Computing (Version 2.14.2). Available at http://www.R project.org/

Reta R., Martos P., Perillo G.M.E., Piccolo M.C., Ferrante A. 2001. Características hidrográficas del estuario de la laguna Mar Chiquita. In: Iribarne O. (ed.), Reserva de Biósfera Mar Chiquita: Características físicas, biológicas y ecológicas. Editorial Martín, Mar del Plata, pp. 31-52.

Rodríguez K.A., Macchi G.J., Acha E.M., et al. 2008. Spawning and fecundity of Jenyns's sprat, Ramnogaster arcuata, a winter spawner in the temperate waters of the Río de la Plata estuary, Argentina-Uruguay. J. Mar. Biol. Ass. U. K. 88: 423-429.

Rosso J.J. 2006. Peces Pampeanos: Guía y Ecología. Editorial L.O.L.A., Buenos Aires, 224 pp.

Sánchez R.P., Ciechomsky de J.D. 1995. Spawning and nursery grounds of pelagic fish species in the sea-shelf off Argentina and adjacents areas. Sci. Mar. 59: 455-478.

Stoner A.W., Manderson J.P., Pessutti J.P. 2001. Spatially explicit analysis of estuarine habitat for juvenile winter flounder: combining generalized additive models and geographic information systems. Mar. Ecol. Progr. Ser. 213: 253-271. http://dx.doi.org/10.3354/meps213253

Strydom N.A. 2003. Occurrence of larval and early juvenile fishes in the surf zone adjacent to two intermittently open estuaries, South Africa. Env. Biol. Fish. 66: 349-359. http://dx.doi.org/10.1023/A:1023949607821

ter Braak C.J.F., Verdonschot P.F.M. 1995. Canonical correspondence analysis 592 and related multivariate methods in aquatic ecology. Aquat. Sci. 57: 255-289. http://dx.doi.org/10.1007/BF00877430

Valiñas M., Acha E.M., Iribarne O. 2010. Habitat use and feeding habits of juvenile fishes in a infrequently flooded Atlantic saltmarsh. Mar. Freshw. Res. 61: 1154-1163. http://dx.doi.org/10.1071/MF09109

Vasconcelos R.P., Reis-Santos P., Maia A., et al. 2010. Nursery use patterns of commercially important marine fish species in estuarine systems along the Portuguese coast. Estuar. Coast. Shelf Sci. 86: 613-624. http://dx.doi.org/10.1016/j.ecss.2009.11.029

Watt-Pringle P., Strydom N.A. 2003. Habitat use by larval fishes in a temperate South African surf zone. Estuar. Coast. Shelf Sci. 58: 765-774. http://dx.doi.org/10.1016/S0272-7714(03)00183-5

Whitehead P.Y.P. 1985. FAO Species catalogue. Clupeioid fishes of the world (Suborder Clupeoidei). Chirocentridae, Clupeidae and Pristigasteridae. FIR/S125 Vol. 7, pp. 1-303.

Whitfield A.K. 1994. Abundance of larval and 0+ juvenile marine fishes in the lower reaches of three southern African estuaries with differing freshwater inputs. Mar. Ecol. Progr. Ser. 105: 257-267.

http://dx.doi.org/10.3354/meps 105257 